www.ijip.in | ISSN: 2348-5396 (e) | ISSN: 2349-3429 (P)

Volume: 6, Issue: 1, January-March, 2018

DOl:10.25215 | DIP:18.01 | IF. 6.9 (ICI)

\title{
A STUDY ON ASSESSMENT OF STRESS AND ITS MANAGEMENT IN HOSPITAL EMPLOYESS
}

\section{MR. NOORUL AMUIN \\ DR. MUZAMILL AHJMAD}




\title{
(4.T) The International Journal of \\ 1 INDIAN PSYCHOLOGY
}

\author{
Volume 6 \\ Issue 1 \\ January-March, 2018
}

A STUDY ON ASSESSMENT OF STRESS AND ITS MANAGEMENT IN HOSPITAL EMPLOYESS

MR. NOORUL AMIN

M.Sc Counselling and Family Therapy Scholar, IGNOU

DR. MUZAMIL AHMAD

Lecturer GDC Ganderbal, Academic Counsellor IGNOU 1209 


\section{THE INTERNATIONAL JOURNAL OF INDIAN PSYCHOLOGY}

This Issue (Volume 6, Issue 1) Published, March, 2018

\section{Headquarters;}

REDSHINE Publication, 88, Patel Street, Navamuvada, Lunawada, Gujarat, India, 389230

Author Helpline: +91 7698826988

Copyright (C) 2018, IJIP

No part of this publication may be reproduced, transcribed, stored in a retrieval system, or translated into any language or computer language, in any form or by any means, electronic, mechanical, magnetic, optical, chemical, manual, or otherwise, without the prior written permission of RED'SHINE Publication except under the terms of a RED'SHINE Publishing Press license agreement.

ISSN (Online) 2348-5396

ISSN (Print) 2349-3429

ZDB: $2775190-9$

IDN: 1052425984

CODEN: IJIPD3

OCLC: 882110133

WorldCat Accession: (DE-600) ZDB2775190-9

ROAR ID: 9235

Impact Factor: 3.3 (2015) from the InfoBaselndex, Mysore, India

Price: 500 INR/- | \$ 8.00 USD

2018 Edition

Website: www.ijip.in

Email: info.ijip@gmail.com

Please submit your work's abstract or introduction to (info.ijip@gmail.com | www.ijip.in) IJIP's all content automatic indexed to Google Scholar, Google Book Programs. 
The Editorial Board is comprised of nationally recognized scholars and researchers in the fields of Psychology, Education, Social Sciences, Home Sciences and related areas. The Board provides guidance and direction to ensure the integrity of this academic peer-reviewed journal.

\section{Editor-in-Chief :}

Prof. Suresh M. Makvana, Ph.D

Professor and Head, Dept. of Psychology, Sardar Patel University. Vallabh Vidhyanagar, Gujarat,

Chairman, Board of Study, Sardar Patel University, Gujarat State,

Chief Editor: International Journal of Social Impact,

INDIA

\section{Editor :}

Ankit Patel,

Clinical Psychology

Author of 20 Psychological Books (National and International Best Seller)

INDIA

Editorial Advisors :

Dr. D. J. Bhatt, Ph.D

ex. Head, Professor, Dept. of Psychology, Saurashtra

University, Rajkot, Gujarat

INDIA

\section{Dr. Tarni Jee, Ph.D}

President, Indian Psychological Association (IPA)

Professor, Dept. of Psychology, University of Patana,

Patana, Bihar,

INDIA

Prof. M. V. R Raju, Ph.D

Head \& Prof, Dept. of Psychology, Andhra University, Visakhapatnam

INDIA

\section{Dr. John Michel Raj. S, Ph.D}

Dean, Professor, Dept. of Social Science, Bharathiar University, Coimbatore, Tamilnadu,

INDIA

\section{Prof. C.R. Mukundan, Ph.D, D. M. \& S. P}

Professor Emeritus / Director, Institute of Behavioural Science, Gujarat Forensic Sciences University, Gandhinagar, Gujarat.

Author of 'Brain at Work'

INDIA

Dr. Panchajanya Paul, (MD , ABPN , ABIHM, FAPA)

American Board Certified Child, Adolescent and Adult Psychiatrist

Diplomate, American Board of Psychiatry \& Neurology Diplomate, American Board of Integrative and Holistic Medicine ( $A B I H M$ )

Fellow of American Psychiatric Association ( FAPA) UNITED STATES

\section{Co-Editor(s):}

\section{Dr. Samir J. Patel, Ph.D}

Ex. Professor, Dept. of Psychology, Sardar Patel University, Vallabh Vidhyanagar, Gujarat,

\section{Dr. Ashvin B. Jansari, Ph.D}

Dept. of Psychology, Gujarat University, Ahmadabad, Gujarat,

INDIA

\section{Dr. Savita Vaghela, Ph.D}

Head, Dept. of Psychology, M. K. Bhavanagar

University, Bhavnagar, Gujarat,

INDIA

\section{Dr. Sangita Pathak, Ph.D}

Associate Professor, Dept. of Psychology, Sardar Patel University, Vallabh Vidhyanagar, Gujarat

INDIA

\section{Associate Editor(s)}

\section{Dr. Amrita Panda, Ph.D}

Rehabilitation Psychologist, Project Fellow, Centre for the Study of Developmental Disability, Department of Psychology, University of Calcutta, Kolkata INDIA

\section{Dr. Shashi Kala Singh, Ph.D}

Associate Professor, Dept. of Psychology, Rachi

University, Jharknand

INDIA
Prof. Akbar Husain (D. Litt.), Ph.D

Coordinator, UGC-SAP (DRS - I) Department of Psychology, Aligarh Muslim University, Aligarh INDIA 
Dr. Pankaj Suvera, Ph.D

Assistant Professor. Department of Psychology, Sardar Patel University, Vallabh Vidhyanagar, Gujarat, INDIA

\section{Dr. Raju. S, Ph.D}

Associate Professor, Dept. of Psychology, University of Kerala, Kerala,

INDIA

\section{Dr. Ravindra Kumar, Ph.D}

Assistant Professor, Dept. of Psychology, Mewar

University, Chittorgarh, Rajasthan,

INDIA

\section{Editorial Assistant(s):}

Dr. Karsan Chothani, Ph.D

Associate Professor, Dept. of Psychology, C. U. Shah

College, Ahmadabad, Gujarat,

INDIA

\section{Dr. R. B. Rabari, Ph.D}

Head, Associate Professor, SPT Arts and Science College, Godhra, Gujarat, INDIA

\section{Dr. Milan P. Patel, Ph.D}

Physical Instructor, College of Veterinary Science and A.H., Navsari Agricultural University, Navsari, Gujarat, INDIA

\section{Dr. Priyanka Kacker, Ph.D}

Assistant Professor, Neuropsychology and Forensic Psychology at the Institute of Behavioral Science, Gujarat Forensic Sciences University, Gandhinagar, Gujarat.

INDIA

\section{Dr. Ajay K. Chaudhary, Ph.D}

Senior Lecturer, Department of Psychology, Government Meera Girls College, Udaipur (Raj.) INDIA

\section{Prof. Asoke Kumar Saha, Ph.D}

Chairman \& Professor, Dept. of Psychology, Jagannath University, Dhaka, Editor-in-Chief, Jagannath University Journal of Psychology, Ex-Proctor, Jagannath University, Ex-Doctoral Fellow, ICSSR, India BANGLADESH

\section{Dr. Subhas Sharma, Ph.D}

Associate Professor, Dept. of Psychology, Bhavnagar University, Gujarat

INDIA

Dr. Yogesh Jogasan, Ph.D

Associate Professor, Dept. of Psychology, Saurashtra University, Rajkot, Gujarat, INDIA

\section{Dr. Shailesh Raval, Ph.D}

Associate Professor, Smt. Sadguna C. U. Arts College for Girls. Lal Darwaja, Ahmedabad, Gujarat. INDIA

\section{Mr. Yoseph Shumi Robi}

Assistant Professor. Department of Educational Psychology, Kotebe University College, Addis Ababa, KUC, ETHIOPIA

\section{Dr. Ali Asgari, Ph.D}

Assistant Professor. Department of Psychology, Kharazmi University, Somaye St., Tehran, IRAN

\section{Dr. Pardeep Kumar, Ph.D}

Assistant Professor, Dept. of Psychology, Lovely Professional University, Punjab INDIA

\section{Dr. G Sai Sailesh Kumar, Ph.D}

PhD, M.SC (Medical Physiology), Assistant Professor, Little flower medical Research Centre, Angamaly, Kerala, INDIA

\section{Dr. Ravikesh Tripathi, Ph.D}

[M.Phil in M.H.\&S. Psy., Ph.D (NIMHANS) PLMIAC Psy, Reg No: A20980] Assistant Professor, NIMHANS INDIA

\section{Peer-Reviewer(s):}

\section{Dr. Mahipat Shinh Chavada, Ph.D}

Chairman, Board of Study, Gujarat University, Gujarat State. Principal, L. D Arts College, Ahmadabad,

Gujarat

INDIA

\section{Dr. M. G. Mansuri, Ph.D}

Head, Dept. of Psychology, Nalini Arts College, Vallabh Vidhyanagar, Gujarat,

INDIA

\section{Dr. Navin Patel, Ph.D}

Convener, Gujarat Psychological Association (GPA) Head, Dept. of Psychology, GLS Arts College, Ahmadabad, Gujarat,INDIA

\section{Dr. Bharat S. Trivedi, Ph.D}

Head, Associate Professor, Dept. of Psychology, P. M. Pandya Arts, Science, Commerce College, Lunawada, Gujarat, INDIA 
Lexi Lynn Whitson

Research Assi. West Texas A\&M University, Canyon, UNITED STATES

\section{Dr. Mark Javeth, Ph.D}

Research Assi. Tarleton State University, Stephenville, Texas,

UNITED STATES

\section{Dr. Varghese Paul K, Ph.D}

Head, P.G. Dept. of Psychology, Prajyoti Niketan

College, Pudukad,

Aided \& Affiliated to University of Calicut, Kerala, INDIA

\section{Dr K. Parameswaran, Ph.D}

Professor, Symbiosis Law School, Pune

(International Law, Jurisprudential Psychology of

Penology and Victimology),

INDIA

\section{Deepti Puranik (Shah)}

Assistant Director, Psychology Department, Helik Advisory LimitedAssociate Member of British and European Polygraph Association.

INDIA

\section{Dr. Santosh Kumar Behera, Ph.D}

Assistant Professor, Department of Education, SidhoKanho-Birsha University, Purulia, West Bengal, INDIA

\section{Nayanika Singh}

Assistant Professor, Department of Psychology at

D.A.V. College, sector-10, Chandigarh. INDIA

\section{Dr. Soma Sahu, Ph.D}

Lecturer, Teaching Psychology, Research

Methodology, Psychology Dept. Bangabasi College,

Kolkata

INDIA

Mr. Ansh Mehta, (Autism Expert of Canada)
Autism \& Behavioral Science, George Brown College,
CANADA

\section{Richard Harvey}

\section{(Psycho-Spiritual Psychotherapist)}

Author and Spiritual Teacher, Founder-Director of the Change Workshops (1986-1995).

SPAIN
Dr. Rūta Gudmonaitè, Ph.D

Project Manager, Open University UK, Milton Keynes, England,

UNITED KINGDOM

\section{Dr. S. T. Janetius, Ph.D}

Director, Centre Counselling \& GuidanceHOD, Department of Psychology, Sree Saraswathi Thyagaraja College, Pollachi INDIA

\section{Dr. Vincent A. Parnabas, Ph.D}

Senior Lecturer, Faculty of Sport Science and Recreation, University of Technology Mara, (Uitm),

Shah Alam, Selangor.

MALAYSIA

\section{Dr Amita Puri, Ph.D}

Associate Professor, Dept of Behavioral Sciences, Amity University, Gurgaon,

INDIA

\section{Dr. Dileep Sharma, Ph.D}

Asstt. Professor, Department of Special Education Psychology, Sardar Patel University, Vallabh Vidyanagar, Anand, INDIA

\section{Heena Khan}

Assistant Professor, P.G. Department of Psychology, R.T.M. Nagpur University, Nagpur, Maharashtra, INDIA

\section{Mohammad Reza Iravani}

Assistant Professor, Department of Social work, Azad, University of Khomeinishahr, Islamic Azad University, Khomeinishahr branch, Khomeinishahr, Esfahan IRAN

\section{Aastha Dhingra (Clinical Psychologist)}

Director \& Co-Founder, Ad Executive Training \& Coaching Pvt Ltd INDIA

\section{Vishal Parmar, (Forensic Psychologist)}

Forensic Psychology, Institute of Behavioural Science, Gujarat Forensic Sciences University, Gandhinagar, Gujarat. INDIA

\section{Ajay Chauhan, M.Phil}

Clinical Psychology, Sardar Patel University, Vallabh Vidyanagar INDIA 



\section{Message from the Desk of Editor}

It gives me immense pleasure to welcome all to explore/publish/ comment in/on our journal, The International Journal of Indian Psychology (IJIP). There are a lot of challenges which the growing psychological face in the realms of basic necessities in life. Psychological thoughts can play a very distinct role in bringing about this change. One of the key objectives of research should be its usability and application. This journal attempts to document and spark a debate on the research focused on psychological research and ideas in context of emerging geographies. The sectors could range from psychological education and improvement, mental health, environmental issues and solution, health care and medicine and psychological related areas. The key focus would however be the emerging sectors and research which discusses application and usability in social or health context.

We intended to publish case reports, review articles, with main focus on original research articles. Over objective is to reach all the psychological practitioners, who have knowledge and interest but have no time to record the interesting cases, research activities and new innovative procedures which helps us in updating our knowledge and improving our treatment.

Finally, I would like to thank RED’SHINE International Publications, for this keepsake, and my editorial team, technical team, designing team, promoting team, indexing team, authors and well wishers, who are promoting this journal. With these words, I conclude and promise that the standards policies will be maintained. We hope that the research featured here sets up many new milestones. I look forward to make this endeavour very meaningful.

Prof. Suresh Makvana, PhD $^{1}$ Editor in Chief, HOD \& Professor, Dept. of Psychology, Sardar Patel University, Vallabh Vidyanagar, Gujarat, India

\footnotetext{
${ }^{1}$ ksmnortol@gmail.com
} 

Ind e x of Volume 6, I s s u e 1 (Special Issue)

\begin{tabular}{|llc} 
No. & \multicolumn{1}{c}{ Title } & $\begin{array}{c}\text { Page } \\
\text { No. }\end{array}$ \\
\hline $\mathbf{1}$ & $\begin{array}{l}\text { CHAPTER 1 } \\
\text { INTRODUCTION }\end{array}$ & $\mathbf{1}$ \\
\hline 2 & $\begin{array}{l}\text { CHAPTER II } \\
\text { REVIEW OF LITERATURE }\end{array}$ & 5 \\
$\mathbf{3}$ & $\begin{array}{l}\text { CHAPTER III } \\
\text { METHOD AND PROCEDURE }\end{array}$ & $\mathbf{8}$ \\
\hline 4 & $\begin{array}{l}\text { CHAPTER IV } \\
\text { DATA ANALYSIS AND INTERPRETATION } \\
\text { CHAPTER V } \\
\mathbf{5}\end{array}$ & 9 \\
\hline 6 & FINDINGS AND CONCLUSION & $\mathbf{1 9}$ \\
\hline
\end{tabular}




\section{DISCLAIMER}

The views expressed by the authors in their articles, reviews etc in this issue are their own. The Editor, Publisher and owner are not responsible for them. All disputes concerning the journal shall be settled in the court at Lunawada, Gujarat.

\section{COPYRIGHT NOTES}

(C) 2017; IJIP Authors; licensee IJIP. This is an Open Access Research distributed under the terms of the Creative Commons Attribution License (http://creativecommons.org/licenses/by/2.0), which permits unrestricted use, distribution, and reproduction in any Medium, provided the original work is properly cited. 


\section{CHAPTER 1 INTRODUCTION}

Stress

Stress refers to the strain from the conflict between our external environment and us, leading to emotional and physical pressure. In our fast paced world, it is impossible to live without stress, whether you are a student or a working adult. There is both positive and negative stress, depending on each individual's unique perception of the tension between the two forces. Stress bears deliberating effects on both the employees and the employer. As per Dr $\mathrm{H}$ seyles, Stress is defined as "a state of psychological and physiological imbalance resulting from the disparity between situational demand and the individual's ability and motivation to meet those needs". The word stress has its origin in the Latin word string ere to draw tight. In the $17^{\text {th }}$ century the word was used to describe affliction and hardship. The meaning of the word later included the concepts of pressure, strain or force. Today the description of stress includes an outside stimulus and the person's response to it. Several studies have focused on the possible relation between stress, illness and different ways people respond to it. These studies distinguish the various aspects of stress which a person may face in life, e.g. stress at home, in personal life or at work. This review focuses on stress at work, with particular emphasis to the nursing profession, in an attempt to explore possible management strategies that may decrease it (Golubic etal., 2009, Lu et al. 2009).

\section{Workplace Stress}

Workplace stress is the harmful physical and emotional response that occurs when there is a poor match between job demands and the capabilities, resources, or needs of the worker. These conditions may lead to poor work performance or even injury. Job stress is also associated with various biological reactions that may lead ultimately to compromised health, such as cardiovascular disease. Stress is a prevalent and costly problem in today's workplace. About one third of workers report high levels of stress. One quarter of employees view their jobs as the number one stressor in their lives. Three quarters of employees believe the worker has more on the job stress than a generation ago. Evidence also suggests that stress is the major cause of turn over in organizations.

\section{Symptoms of Stress}

Absenteeism, escaping from work responsibilities, arriving late, leaving early, etc. Under eating), excessive sleeplessness, etc.

\section{Causes of stress}

Organizational factors like Discrimination in pay/salary structure, strict rules and regulations, Ineffective communication, Peer pressure, Goals conflicts/goals ambiguity, more of centralized and formal organization structure, Less promotional opportunities, Lack of employees participation in decision-making, Excessive control over the employees by the manager's supervisors. Individual factors that are having severe effects on the working person are like one having various expectations from the family members, peers, superior and subordinates, failure to understand such expectations or to convey such expectations lead to role ambiguity/role conflict which in turn causes employee stress. Other individual factors 
causing stress among employees are inherent personality traits such as being impatient, aggressive, rigid, feeling time pressure always, etc. Similarly, the family issues, personal financial problems, sudden career changes all lead to stress. Job concerning factors Monotonous nature of job, Unsafe and unhealthy working conditions, Lack of confidentiality, Crowding Extra organizational factors can be discussed as in today's modern and technology savvy world, stress has increased. Inflation, technological change, social responsibilities and rapid social changes are other extra organizational factors causing stress.

\section{Stress Management}

Stress management is the need of the hour. However hard we try to go beyond a stress situation, life see and plaguing us with anxiety attacks. Moreover, be it our anxiety, mind body exhaustion or our erring attitudes, we tend to overlook causes of stress and the conditions triggered by those. In such unsettling moments we often forget that stressors, if not escapable, are fairly manageable and treatable.

Edwards and Burnard (2003), suggest that the most effective stress management techniques are:

1. Stress management workshops

2. Training in therapeutic skills

3. Training for effective behavioral changes

4. Relaxation techniques

Powell and Enright (1993) describe four main stages which are essential for stress management group viz. The first step in the therapeutic intervention is to provide information and educate the individuals (employees) about stress. The authors point out that only when somebody is aware of a problem and its implications for his/her personal or professional life is a correct reaction possible.

The second step should be the teachings of coping skills which can help the employees feel that they are in control of the problem and of their life in general. The next step should be the setting up of specific behavioral assignments that the therapists involved consider to be helpful for the members of the group.

The last one is to meet other people with similar problems who can offer the employee the chance to feel less alone and different. The sharing of problems and experiences has been proven to encourage improved coping of stress and anxiety.

Stress management techniques which aim to develop effective coping skills should not be based on the belief that a situation in itself is the main stressor but rather, the way a person perceives it. Therefore, the goal is to relearn ways of viewing situations with the use of reasoning and logic and in order to form correct reactions. This helps to deal with attitudes that previously proved to be harmful to the person and stemmed from past habits. A person's ability, experience and personality drive them to appraise an environment as threatening or challenging. If a person feels that they can cope with a situation and take positive action, this 
success results in personal health and wellbeing. An example is the hyperactive workaholic who seeks demanding tasks as a welcome challenge (McNeely, 2005).

\section{Hospital employees}

Here it refers to the staff nurses working in the premier health care institute of Vale skimssoura.

\section{Strategies for Managing Stress}

Organizational strategies for managing stress are encouraging more of organizational communication with the employees so that there is no role ambiguity/conflict. Effective communication can also change employee views. Managers can use better signs and symbols which are not misinterpreted by the employees; Encourage employees 'participation in decision-making. This will reduce role stress; Grant the employees greater independence, meaningful and timely feedback, and greater responsibility; The organizational goals should be realistic, stimulating and particular. The employees must be given feedback on how well they are heading towards these goals Encourage decentralization; Have a fair and just distribution of incentives and salary structure; Promote job rotation and job enrichment; Create a just and safe working environment; Have effective hiring and orientation procedure; Appreciate the employees on accomplishing and over exceeding their targets.

Individual strategies for managing stress are that the employees should make a "todo" list daily, prioritize the acts in the list and plan the acts accordingly. They should take regular breaks during work to relax you, By effective time management, the employees can achieve their targets timely and can meet work pressures and, thus, avoid stress; Do hard work, Strive to achieve your goals but do not do it to the harm of family, health, or peer; Indulge in physical exercises. It helps in effective blood circulation, keeps you fit, diverts mind from work pressures; Encourage a healthy lifestyle. Take a regular sleep, have plenty of water, have healthy eating habits. Promote relaxation techniques such as yoga, listening music, practicing ones religion and meditation;

The employees should have optimistic approach about their work. They should avoid connections with negative approach employees; The employees should have emotional intelligence at workplace.They should have self-awareness, self-confidence and self-control at workplace; The employees should build social support. They should have close connections with trustworthy peer who can listen to their problems and boost their confidence level. This social network will help the employees to overcome stress; Employee counseling's a very good strategy to overcome employee stress. Through counselling, employees can become aware of their strengths and how to develop those strengths; Their weaknesses and how to eliminate them; And they can develop strategies for changing their behavior. Employees are also given career counselling which helps in reducing their ambiguities with regard to career; Find a fun way to release stress, such as, cracking jokes, playing tennis, golf, exercise etc. and employees should not remain preoccupied with themselves but they should turn their focus outside and should help other coworkers. This will release some of the stress. 


\section{Objectives}

1. To study the causes of stress among employees.

2. To analyze the level of stress on employees.

3. To study the effects of stress on the health of employees.

4. To study the effect of overload on the stress level of employees.

5. To study the role of stress in interpersonal relationship. 


\section{CHAPTER II \\ REVIEW OF LITERATURE}

\section{Review of literature}

Shukla \& Garg, December 2013. The author has discussed that most of the employees fear with the fact that lack quality in their work puts stress on them. It is found that maximum number of employees in banks remains in stress. 50\% employees feel that they are overloaded with work. $44 \%$ employees feel tensed due to their non-achievement of their target of work. 38\% employees accepted that they will obey the order of their boss by sacrificing their important domestic function. It indicates fear and stress among employees.

Masood, Effects of Job Stress on Employee Retention: A Study On Banking Sector of Pakistan ,September 2013) The author has discussed that employees have try to work with energy ability and determination even if they are not provided with the support, they need to perform their tasks with honesty. They are more focused to avoided stress and at their work place decrease directly affects their performance.

Ahmad, 2012. Sensation as if you have no is in charge of in excess of your work or job duties is the largest cause of job stress, captivating on supplementary duties in your job is traumatic. Emotion unconfident concerning the job performance is a main foundation of stress for a lot of people. Hesitation about work roles. Being uncertain about your duties, how your job might be varying, or the goals of your region or corporation can lead to stress. Anxiety on the job frequently comes from deprived communication. Lack of support from your superior or co-worker makes it harder to resolve other troubles at vocation that are causing stress

Dayo Akintayo(2012) found that working environment is significantly related to Workers morale and also working environment is significantly correlated with perceived workers productivity.

Dr. K. Chandrasekar (2011) found that environmental factors are conducive to work and he also found that factors that affect attitude of employees to work are interpersonal relationships control over environment, shift, emotional factors, job assignment, overtime duty, extended work.

L.S. Kang and R.S. Sandhu (2011) in their article said that Stress is an individual's state of mind in an encounter of a demanding situation or any constraint in the organization which $\mathrm{s} /$ he feels harmful or threatening for her/himself. Stress emerges from various energy seeping conditions in the working environment.

According to Pratibha Garg (2010) Job or occupational stress is mismatch between the individual capabilities and organizational demands. Employees often experience stress because of work overload, an expected work pace, difficult work schedules, role conflict, uncertainty regarding job security, poor interpersonal relationships and unpleasant working conditions. This stress manifests in conflict, depression, headaches, hypertension, alcoholism 
and other conditions. The organizations do not only lose money by paying medical bills but there is a loss of productivity.

R Neelamegam and S Asrafi (2010) in their article said that Stress is a general term applied to the pressures felt in life. Stress at work is almost inevitable in many jobs. It has become a major buzzword and a legitimate concern of the time.

According to N Kathirvel (2009) Stress is the reaction that people take due to excessive pressure or other types of demand placed on them. It arises when they worry that they cannot cope. Stress is a demand made upon the adaptive capacities of the mind and body.

Kulkarni (2006) in an article Burnout said that rapid change of the modern working life is associated with increasing demands of learning new skills, need to adopt to new types of work, pressure of higher productivity and quality of work, time pressure and hectic jobs are increasing stress among the workforce. Further he added that privatization and globalization have ignited mergers, acquisitions and precarious employment.

A.M Berg et al (2006) of Norwegian police said that the prevalence of subjective health complaints was relatively high and was mainly associated to job pressure and lack of support. Males showed more depressive symptoms than females. All stress factors on frequency were positively associated to the burnout dimensions depersonalization and emotional exhaustion except work injuries.

Sharma, Khera and Khandekar (2006) Computer Related Health Problems among Information Technology Professionals in Delhi a publication in Indian Journal of Community Medicine in January 2006 found more on visual stress and musculoskeletal symptoms, initially being mild and temporary and later with increasing years assuming more intense and permanent nature. It also found that computer related morbidity had become an important occupational health problem and of great concern. It suggested an immediate need for the concerned authorities to collaborate and enforce suitable preventive measures.

Barhem et al (2004) define stress as an extraordinary state affecting individual human functions as an outcome of internal and external factors which differ qualitatively(having different types of stressors) and quantitatively (having different numbers of stressors) from individual performance, due to individual differences.

Cobb (1975) has the opinion that, "The responsibility load creates severe stress among workers and managers." If the individual manager cannot cope with the increased responsibilities it may lead to several physical and psychological disorders among them.

Brook (1973) reported that qualitative changes in the job create adjust mental problem among employees. The interpersonal relationships within the department and between the departments create qualitative difficulties within the organization to a great extent. 
Garret \& McDaniel (2001) reported that changes in the health care structure and the nature of patient acuity, new technologies and a focus on cost effective quality of care approach to nursing may have contributed to higher levels of role stress for nurses. Previous research findings are suggesting that role stress in nursing is caused by having little control in one's job, high job demands and lack of support from peers.

Rebecca et al. (2007) found that nurses reported moderate levels of burnout. Role overload and role boundary contributed to higher levels of emotional exhaustion. Role boundary contributed to higher levels of depersonalization and role boundary and role ambiguity contributed to lower levels of personal accomplishment.

Gandi et.al. (2011) found moderate level burnout among Nigerian nurses due to work home and homework interference.

Jinky (2008) found organizational role stress causing burnout among nurses in Philippines. Saini et al. (2011) found that 92\% nurses experienced average level stress and $8 \%$ nurses high level stress due to workload, decreases job autonomy, inadequate supervisor support, less opportunities for learning, and inappropriate feedback. Nurses who are stressed have higher absenteeism rates, lower work satisfaction and are more likely to leave the organization. Baba et al (1999) reported that as role pressure mounts, nurses experience stress and tend to burn out.

Holloway and Wallinga (1990) found that role ambiguity and role conflict were significantly correlated with burnout and role ambiguity was a stronger predictor of burnout.

Elani and Theodoros (2010) found that role ambiguity, lack of power, and role conflict are linked to stress among nurses. Numbers of studies suggest that patient outcomes and nurse burnout are both strongly associated with low staffing levels and poor practice environments. 
CHAPTER III

METHOD AND PROCEDURE

Research Design

This study is explanatory in nature.

\section{Sample}

The sample of the study was selected from a local hospital in Srinagar, Kashmir. The sample consists of staff nurses working in the hospital .The sample size is 40 . It was collected from the employees of a tertiary care hospital in Kashmir skims soura. Non probability sampling technique convenient sampling was done. Data was collected through modified stress questionnaire earlier developed by $\mathrm{H}$ shukhula and $\mathrm{G}$ Rachita .Books, internet web sites, journals etc. were used as a source of secondary data.

MS Excel and MS Word were used to store the data.

\section{Procedure}

The tool was provided to the employees with instructions written on it. They were asked to be part of this research to meet the objectives of this study. The employees who agreed were asked to fill the tool by making appropriate mark on yes or no on each question. While Analyzing the Data each Yes Mark was Given a Score of One and for each No Zero was given. After the tool was filled by employees, it was taken back with thanks. 


\section{CHAPTER IV \\ DATA ANALYSIS AND INTERPRETATION}

Data analysis and interpretation

Percentage Analysis was used to analyze and interpret results and achieve objectives of the research study.

\section{Q 1 Are you content with the performance you give at your institute?}

\section{0}

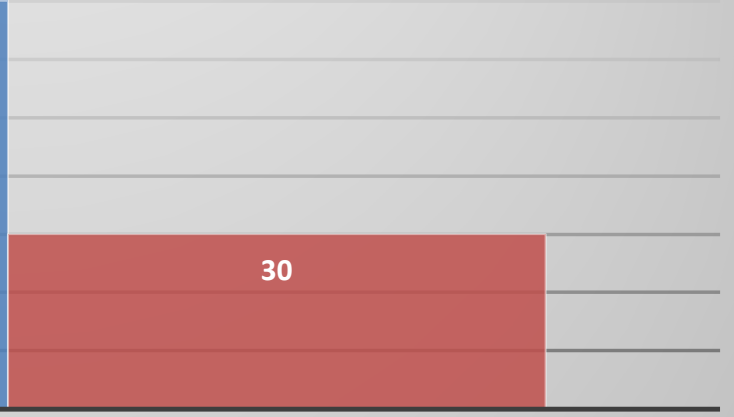

Q 1

- Yes $\square$ No

\section{Q2 Do you fear about the quality of your performance}

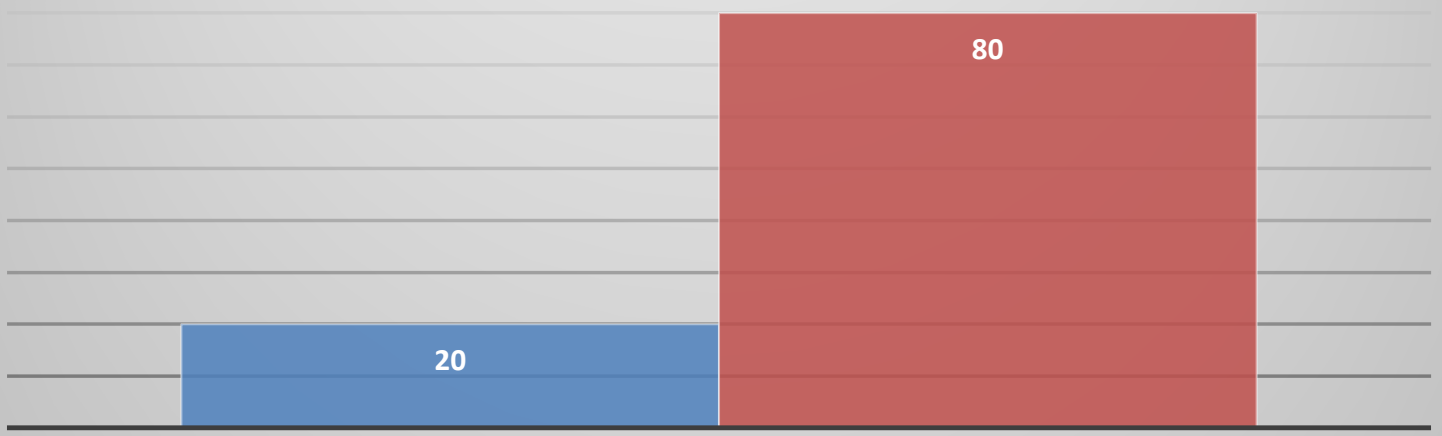

Q2

- Yes no

9 | The International Journal of Indian Psychology (ISSN: 2348-5396) 


\section{Q 3 Do you work more than 8 hours?}

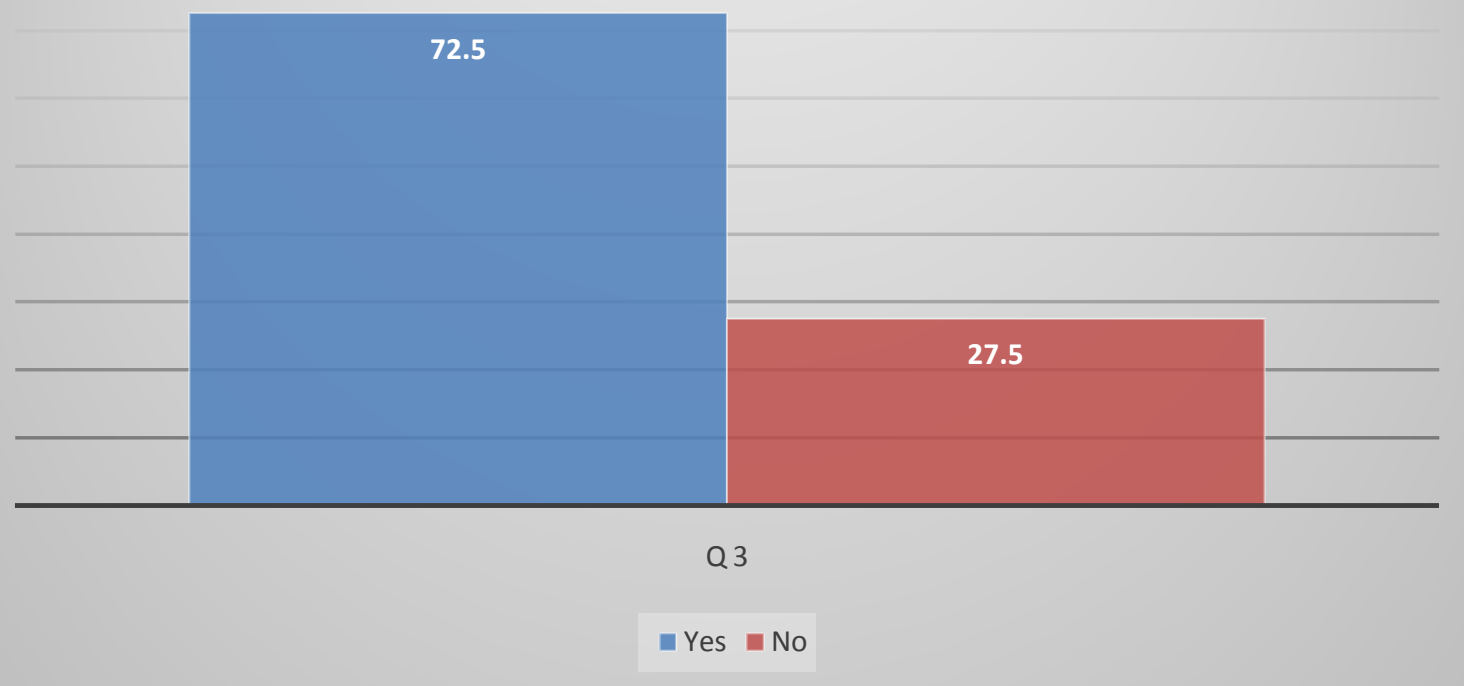

\section{Q 4 Do you worry about your colleagues' opinion about you?}

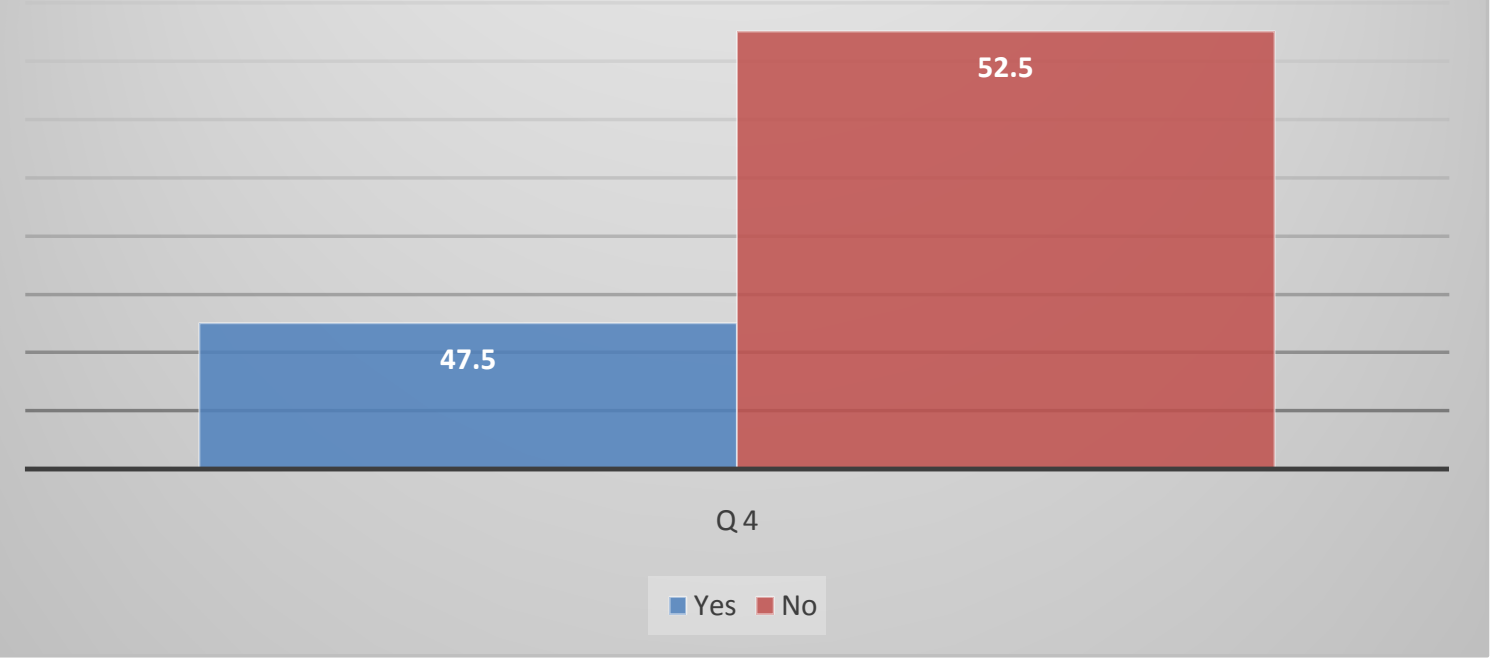




\section{Q 5 Do you feel stress sometimes?}

95

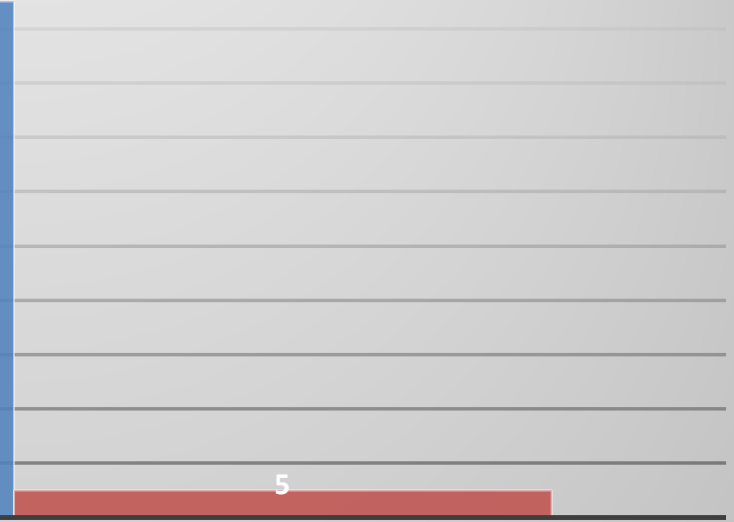

Q5

$\square$ Yes $\square$ No

\section{Q 6 Is workload the reason of your stress?}

82.5 


\section{Q 7 Do you discuss your problem with your spouse or friend or any other person close to you?}

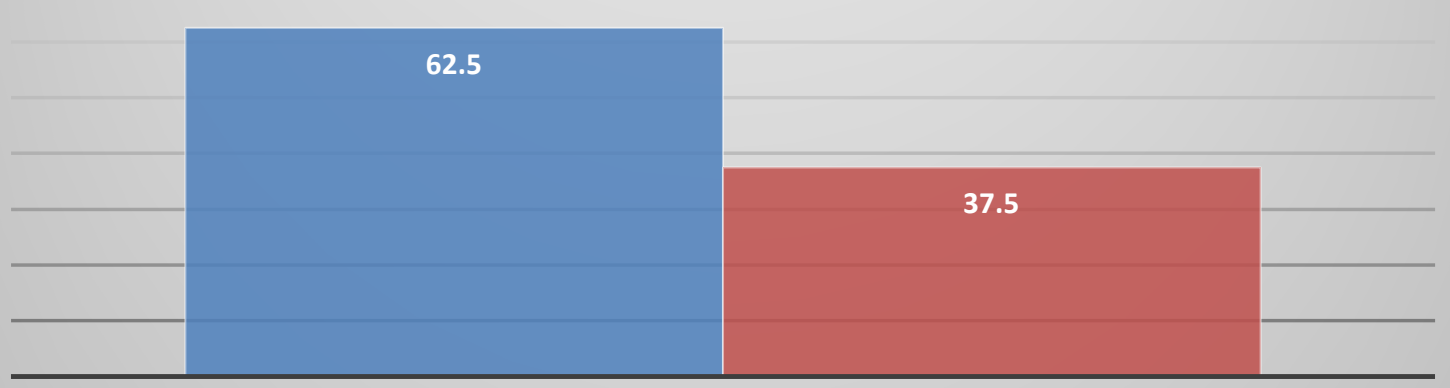

Q 7

$\square$ Yes $\square$ No

\section{Q 8 Do you get tensed at non achievement of your target?}

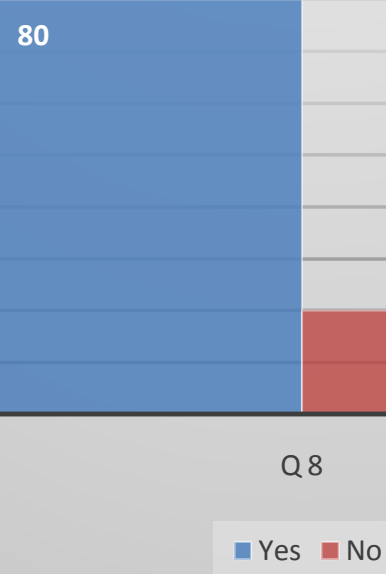

20

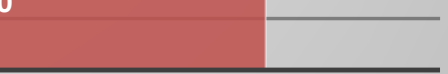

$\square$ Yes $\square$ No 


\section{Q 9 Is there any effect of work on your health?}

95

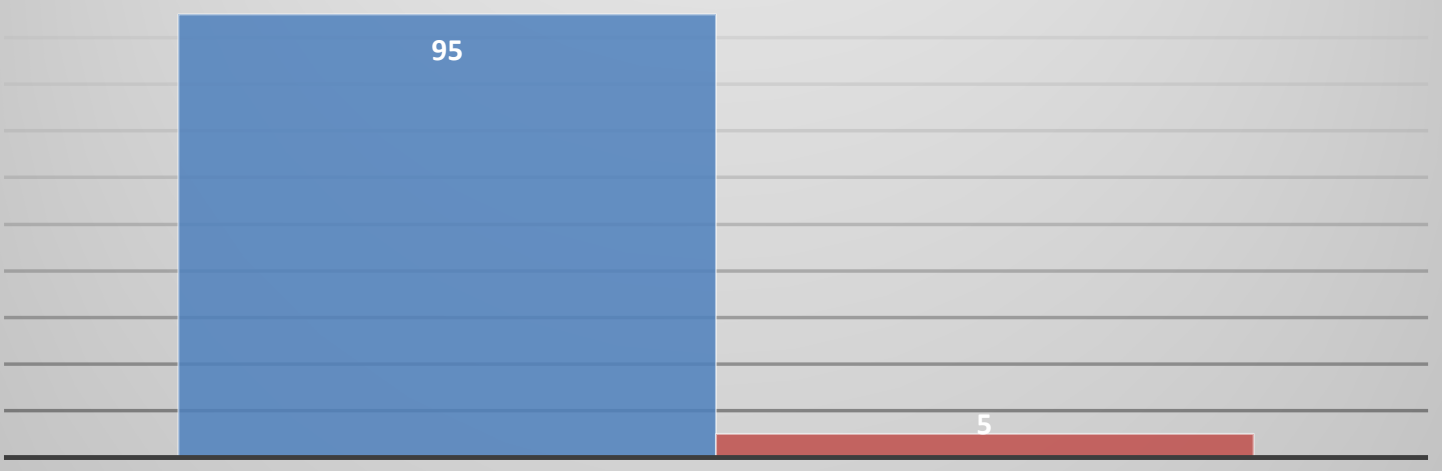

Q6

$\square$ Yes $\square$ No

\section{Do you plan your work before doing?}




\section{Q 11 You have an important function at your} home and if your supervisor asks for Extension of duty, do you agree?

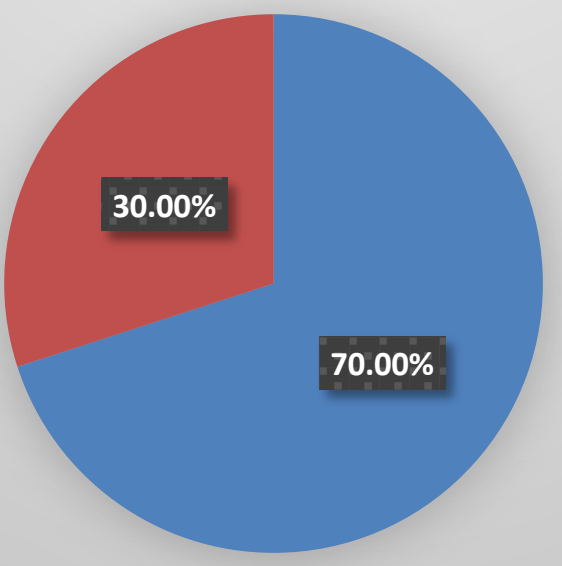

- Yes

No

\section{Q 12 Is there any conflict among employees?}

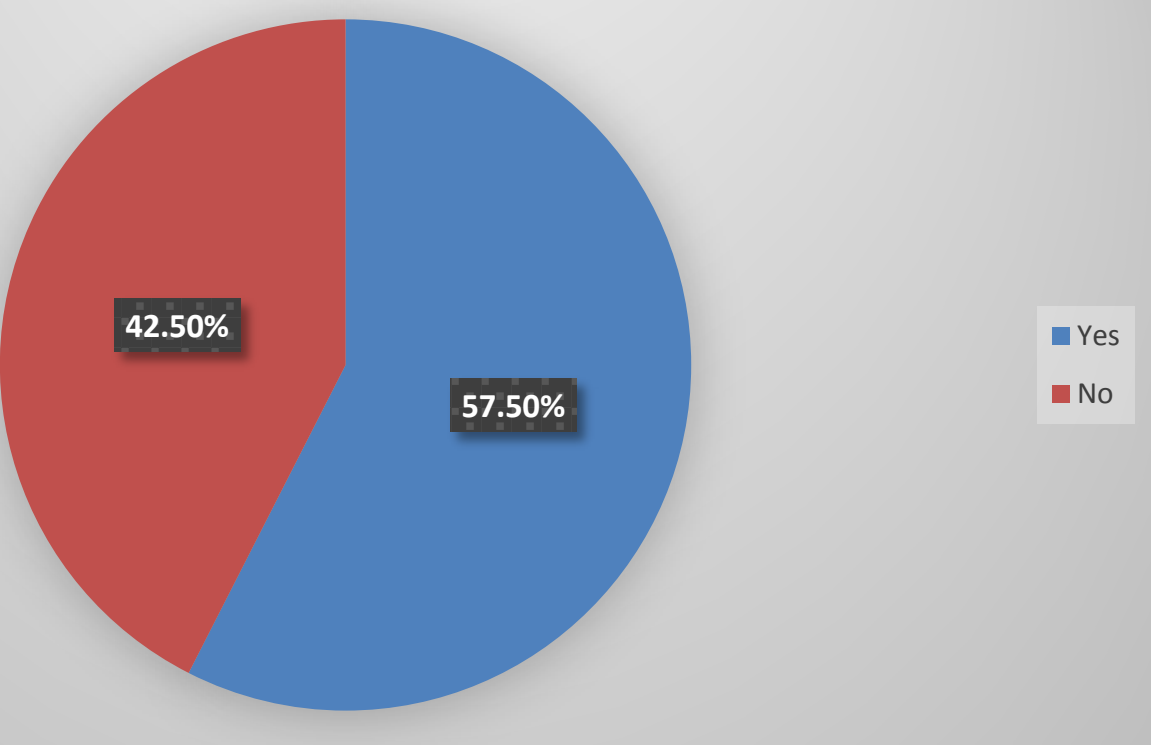




\section{Q 13 Is the conflict resolved in time?}

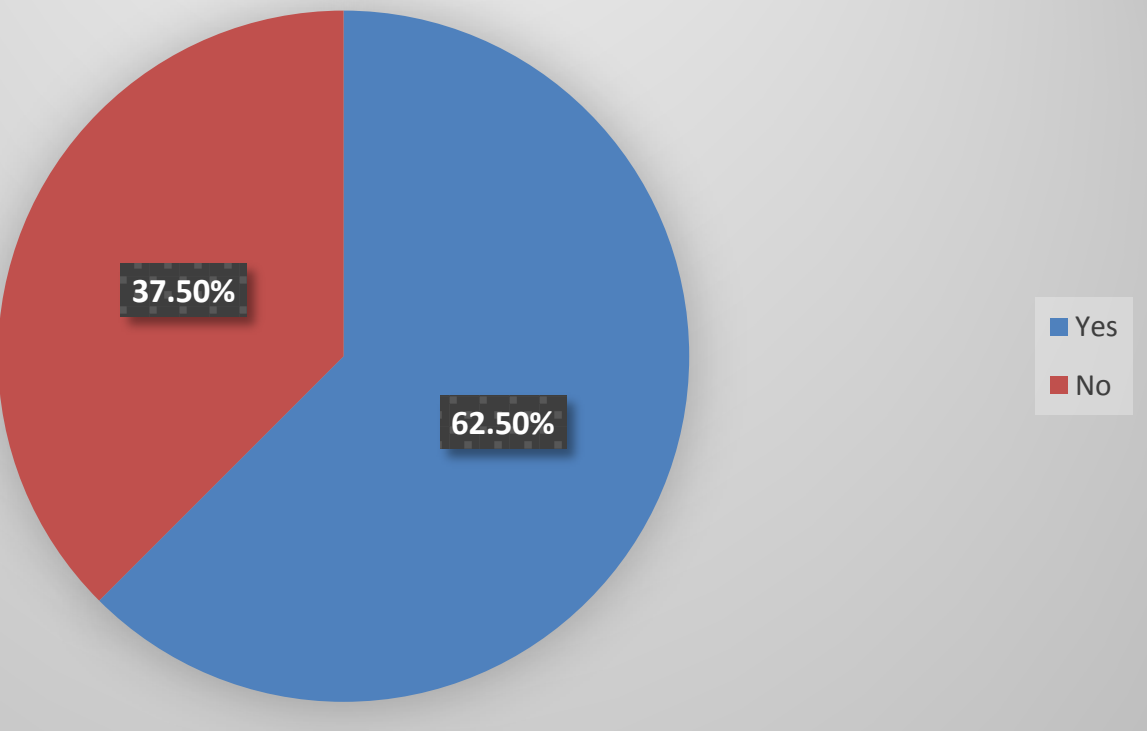

\section{Q 14 Do employees support each other?}

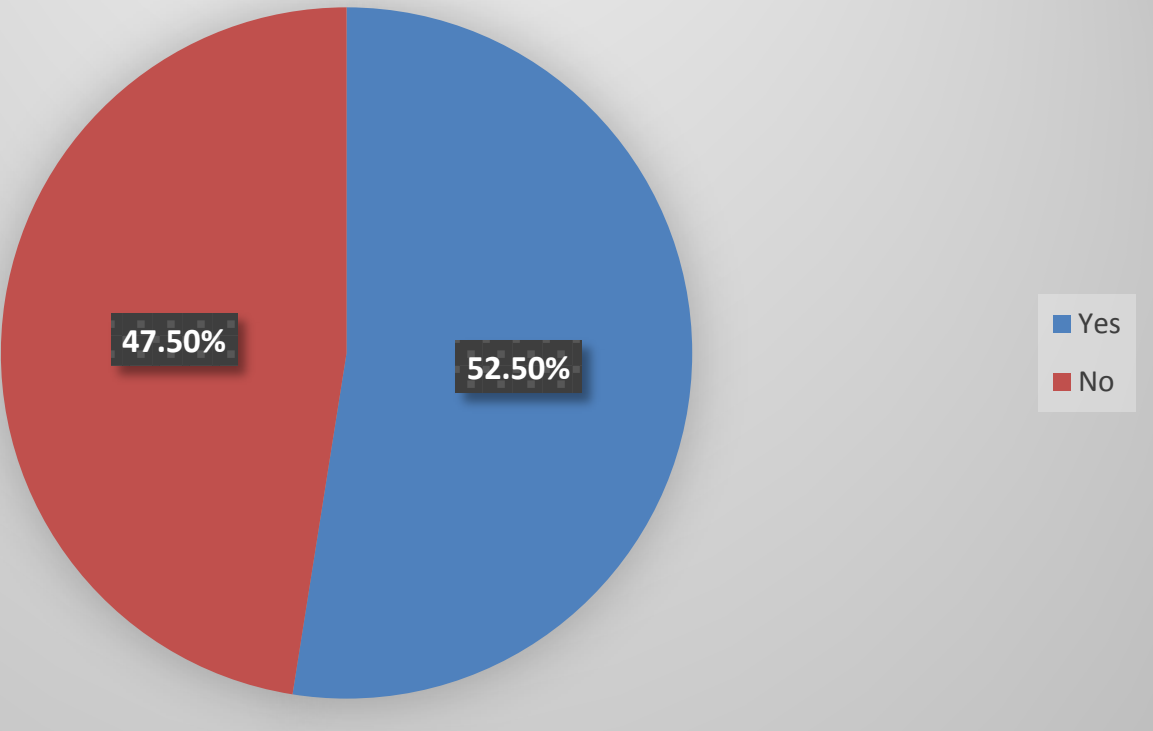

15 | The International Journal of Indian Psychology (ISSN: 2348-5396) 


\section{Q 15 Are the strategies effective that are used by your institute to manage stress of employees?}

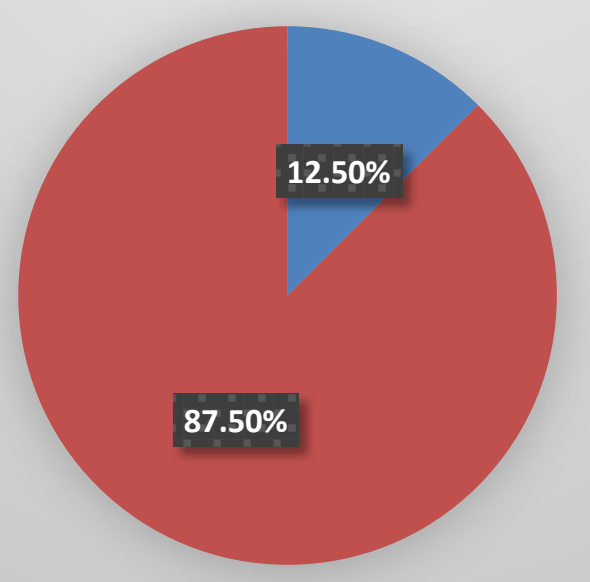

\section{Q 16 Is your social life balanced?}

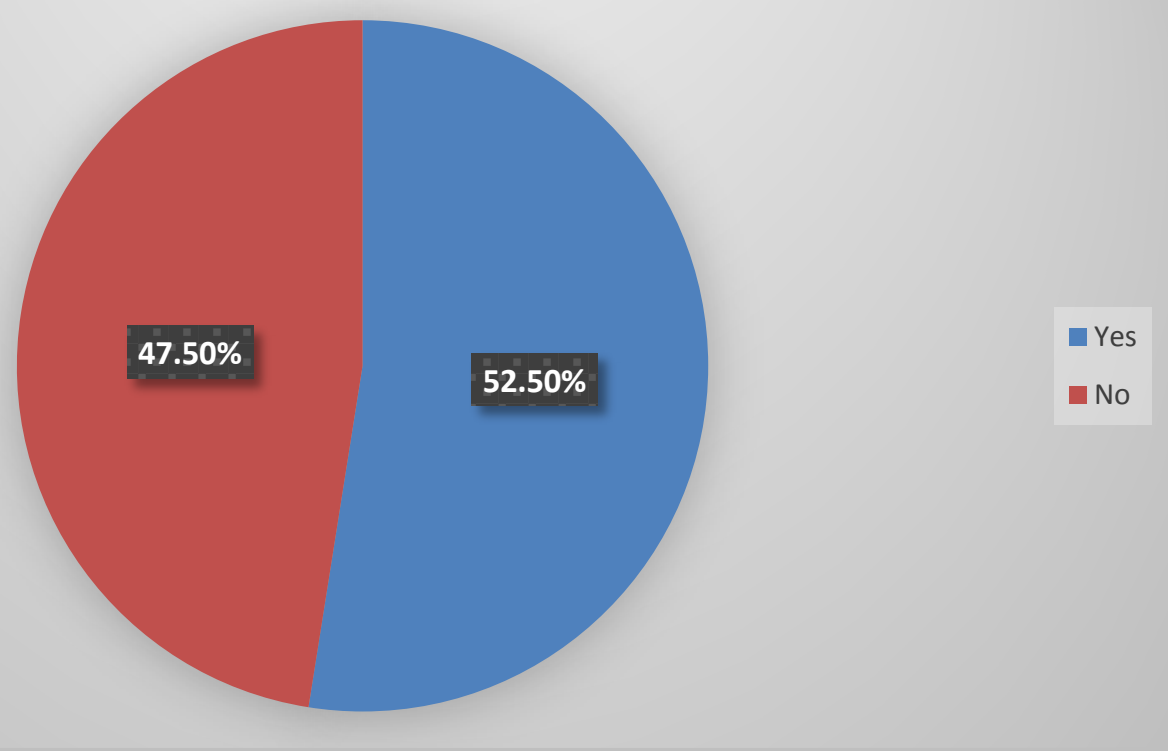




\section{Q 17 Are you stressed because of your family problem?}

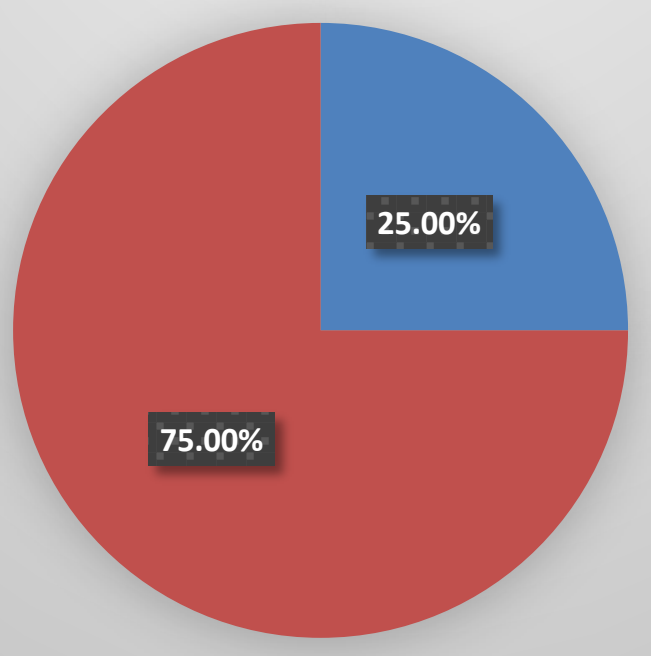

\section{Q 18 Do you try to find any solution for the problem of your Stress?}

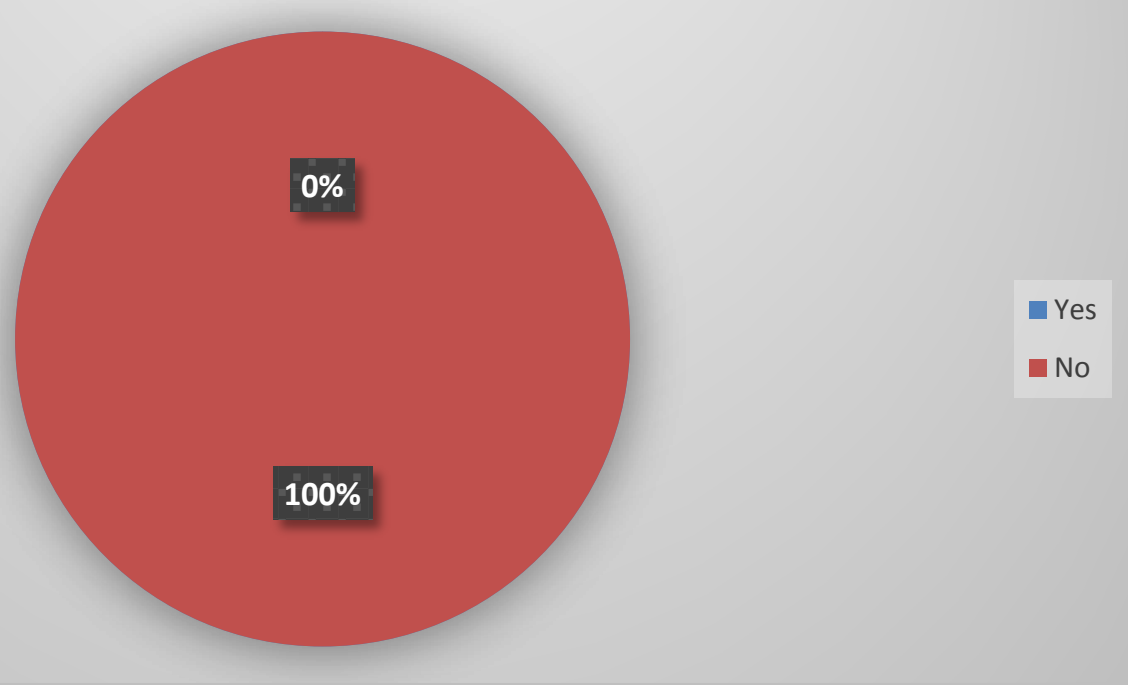




\section{Q 19 Do you try to relieve stress by practicing religion?}

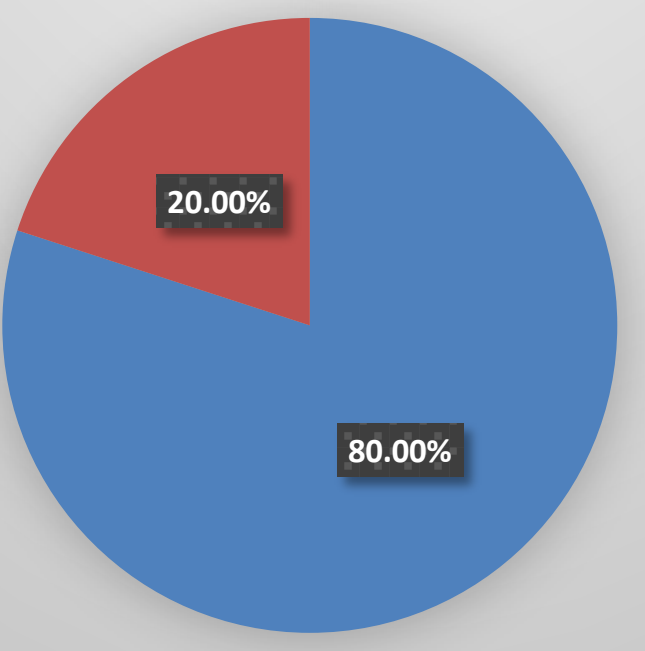

\section{Q 20 Do you regularly spend time on} entertainment?

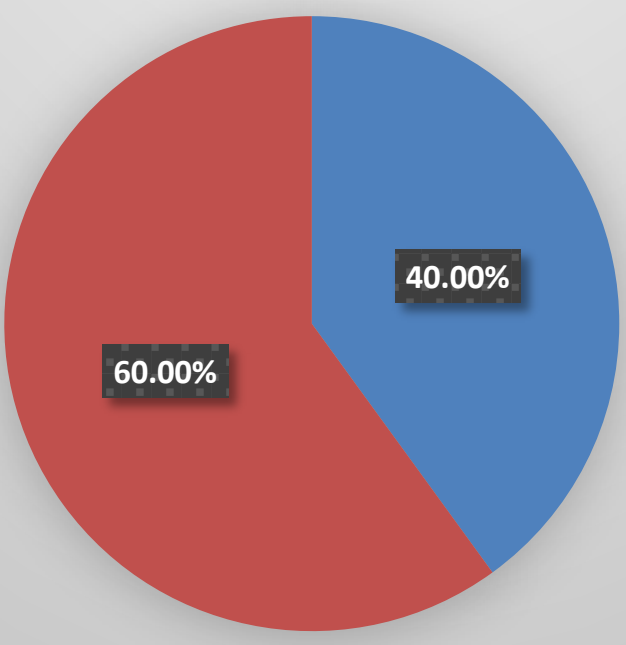

18 | The International Journal of Indian Psychology (ISSN: 2348-5396) 


\section{CHAPTER V \\ FINDINGS AND CONCLUSION}

\section{Findings}

The findings of this study were obtained by percentage analysis. About $70 \%$ of employees were content with the work performance and about $20 \%$ fear about the quality of performance. About $72.5 \%$ of the respondents responded that they work more than 8 hours as is a well-established fact that they have to work for night shifts as well. Majority of the respondents that is $52.5 \%$ don't worry about the opinion of co-workers about them. Most of the employees fear with the fact that lack quality in their work puts stress on them. It is found that maximum number of employees that is $95 \%$ in the hospital remains in stress. $82.5 \%$ employees feel that they are overloaded with work. Most of the respondents that is $62.5 \%$ discuss their problem with their spouse, friend and other persons. 80.0\%Employeesfeel tensed due to their non-achievement of their target of work.95\% of the employees feel that their health is affected by the stress caused by the work. $65 \%$ of the employees agree with planning of work before doing the same.70.0\% employees accepted that they will obey the order of their higher officials by sacrificing their important domestic function. It indicates fear and stress among employees. 57.5\% of the employees accepted that there is conflict among the employees and $62.5 \%$ of employees agree with the fact that it gets resolved in time. 52.5\% employees say that they support each other. Majority of the Nursing officers 87.5\% feel that strategies used by the institute to manage stress are inadequate and ineffective. About 52.5\% feel that their life is balanced. Only 25 \% Employees feel stress due to their family related problems. It means such employees feel greater level of stress as compared to other employees. It is a concern for topmanagement and hospital administration.100\% of the employees tries to find solution to relieve them from stress. $80 \%$ employees practice religion to relieve from stress. In spite of stress, $52.5 \%$ of the employees have good balance in their social life.

The findings are in tune with the findings of researches carried out by Shukla H and Garg M. $\mathrm{R}$ and Ahmad.

\section{Suggestions}

As most of the employees feel that they feel stress at work, hospital administration should take positive steps to make their employees free from stress so that they can work with optimum efficiency and effectiveness.

There should be only one line of authority and employee should not get instructions from more than one supervisor or Senior. Employees of the hospitals should be made free from not only fear of quality of performance but also from other types of fear generating in their minds. However it should not affect the quality patient care and performance.

Guidance and counseling, quality consciousness, awareness programs, psychological support can be provided to employee's .Moreover there should be a post for psychotherapist or clinical psychologist in hospital who will address the problems of employees suffering from 
stress so that they can learn different coping styles that will help them to carry out their professional duties and social duties.

Institutions should arrange therapies, meditation camp, entertaining programs, practicing religion, yoga etc. The working environment should be made clean and safer. There should be proper work division in all departments.

There should be friendly environment within colleagues and especially supervisors. Employees should try for quality of performance in patient care rather than fear from it.

\section{Limitations of Study}

As it was a mini research and the sample size was small, there were some limitations in the study. First of all, the time period for carrying out the research was short as a result of which many facts have been left unexplored. Lack of time and other resources as it was not possible to conduct survey at large level. The targeted sample size was 50 but only 40 employees responded positively. The study is limited to the employees of alone tertiary care hospital in Kashmir located in Srinagar district of j\&k state and therefore the findings of the study cannot be extended to other areas. During collection of the data many employees were unwilling to fill the questionnaire due to lack of time, as it was proposed to have 50 samples but only 40 responded positively. Respondents were having a feeling of wastage of time for them and no applicability. Convenient sampling has been used in the study and it has its own limitations. Personal bias of the respondents might have crept in while answering a few questions. Results of the study may not be generalized.

\section{Scope for Further Studies}

Area of present study can be increased from district level to state level, national level, as well as international level; Sample size can be increased; Other demographic details can be added in the future research like qualification, experience, and age income etc.Various other statistical tests can be used for comprehensive analysis \& findings. Stress Management techniques can be evaluated with some other tool that are used by the employees.

\section{Conclusion}

The problem of stress is inevitable and unavoidable in the any working sector and same is true for the profession of nursing. A majority of the employees face severe stress- related ailments and a lot of psychological problems. Hence, the management must take several initiatives in helping their employees to overcome its disastrous effect.

Since most of the employees working in the hospital are in stress, the organization should support and encourage to take up roles that help them to balance work and family. The productivity of the work force is the most decisive factor as far as the success of an organization is concerned. The productivity in turn is dependent on the psychosocial wellbeing of the employees and thus satisfaction with quality of care is also affected by the stress of employees. In an age of highly dynamic and competitive world, man is exposed to all kinds of stressors that can affect him on all realms of life. The growing importance of interventional strategies is felt more at organizational level. 


\section{REFERENCES}

Ahmad, M. (2012). An Investigation into Occupational Stress and Job Performance in the Employees of Mobile Phone Companies. International Journal of Management Sciences and Business Research, Vol. 1 (Issue 7).

Anne Marie Berg et al, 'stress burnout'. (2006), Journal of Occupational Medicineand Toxicology, 1:26 doi: 10.1186/17456673126

B. Rogers and P. Travers: "Overview of work related hazards in nursing: Health and safetyissues", in Heart and Lung, Vol. 20, 1991, pp. 486495.

Barhem, Belal, Samsinar, Md. Sidin., Abdullah, Iskandar and Alsagoff , Syed Kadir(2004), New Model for Workplace Stress Patterns, Asian Academy of ManagementJournal, Vol. 9, no.1, 5377.

C. Adey: "Stress: Who cares?", in Nursing Times, Vol. 28, 1987, pp. 5253.

C.L. Cooper: Psychosocial stress in cancer (Chichester, John Wiley, 1984).

C.L. Cooperand R. Payne (eds.): Causes, coping and consequences of stress at work (Chichester, JohnWiley, 1988).

Commission of the European Community: Framework Directive on the workplace, No.89/391/EC (Brussels, 1989).

D.A. Chiriboga, G. Jenkins and J. Bailey: "Stress and coping among hospice nurses: Test ofan analytic model", in Nursing Research, Vol. 32,1983, pp. 294299.

D.G. Barnes: "Times are tough - Brother can you paradigm", in Risk Analysis, Vol.14,1994, pp. 219223.

D.G. Cross and A. Fallon: "A stressor comparison of four speciality areas", in AustralianJournal of Advanced Nursing, Vol. 2, 1985, pp. 2436.

Dayo,Akintayo(2012),Working environment, workers' morale and perceived productivity inindustrial organizations in Nigeria, Education Research Journal Vol. 2(3), 8793.

Dr. K. Chandrasekar (2011), "Workplace environment and its impact on organizational performance in public sector organisations", International Journal of EnterpriseComputing and Business Systems, Vol. 1, Issue 1, January 2011.

J.L. Stehle: "Critical care nursing stress: The findings revisited", in Nursing Research,Vol.30, 1981, pp. 182187.

J.T. Bailey, S.M. Steffen and J.W. Grout: "The stress audit: Identifying the stressors of ICUnursing", in Journal of Nursing Education, Vol. 19,1980, pp. 1525.

K.A. Nichols, V. Springford and J. Searle: "An investigation of distress and discontent invarious types of nursing", in Journal of Advanced Nursing, Vol. 6, 1981, pp. 311 318.

Kang L.S., Sandhu R.S., (October 2011), The Indian Journal of Industrial Relations,Vol. 47, No. 2, 329340, Garg P., (Sep 2010), Case Study, Vol 3, Punjab, 5258

Karasek, R.A. (1979), 'Job demands, job decisionlatitude, and mental strain: implications for job redesign’, Administrative ScienceQuarterly, 24, 285-307.

Karasek, R.A., K.P. Triantis and S.S. Chaudhry (1982), 'Coworker and supervisorsupport as moderators of associations between task characteristics and mental strain',Journal of Occupational Behavior, 3(2),181-200. 
Kathirvel N,(2009), The IUP Journal of Management Research, Vol. VIII, No. 11,2844Neelamegam R and Asrafi S,(2010), The IUP Journal of Management Research, Vol.IX, No. 5, 5769

Kulkami G.K., Burnout, (2006), Indian Journal of Occupational \&Environmental Medicine, 10, 34,

L.R. Murphy: "Occupational stress management: A review and appraisal", in Journal ofOccupational Psychology, Vol. 57, 1984, pp. 115.

L.R. Murphy: "Workplace interventions for stress reduction and prevention", in

Masood, A. (September 2013). Effects of Job Stress on Employee Retention: A Study On Banking Sector of Pakistan. International Journal of Scientific and Research Publications, Volume 3, Issue 9 , 1-8.

N Chowdhury and Menon, S. (1997), Beating Burnout, India Today, 9 June, 86

P. Dewe: "New Zealand ministers of religion: Sources of stress and coping strategies"., inWork and Stress, Vol. 1,1987, pp. 351363.

R. Skinner: Microbiological risk assessment and public health, paper presented to theInternational Conference on Risk Assessment, London, 1992.

S. Cox and R. Tait: Safety, reliability and risk management (London, ButterworthHeinemann, 1991).

S. Cox: Riskassessment toolkit (Loughborough, Centre for Extension Studies, Loughborough Universityof Technology, 1992).

Sharma A.K., Khera S. andKhandekar J., (2006), 'Computer Related Health Problems among InformationTechnology Professionals in Delhi, 'Indian Journal of Community Medicine ', 31 (1)

Shukla, H., \& garg, M. R. (december 2013 ). a study on stress management among the employees of nationalised banks. voice of research vol. 2, issue 3 , 72-75.

T. Cox and A. Griffiths: "The nature and measurement of work stress: Theory and practice",in N. Corlett and J. Wilson (eds.): Evaluation of human work: A practical ergonomicsmethodology (London, Taylor and Francis, 1994).

T. Cox and S. Cox: Psychosocial and organizational hazards: Monitoring and control,European Series in Occupational Health No.5 (Copenhagen, World Health Organization,1993).

T. Cox, A. Griffiths and S. Cox: "Stress explosion: Managing stress at work", in Health andSafety at Work, June 1993, pp. 1618.

T. Cox: Stress research and stress management: Putting theory to work (Sudbury, HSEBooks, 1993).

www.google.com 


\section{A STUDY ON ASSESSMENT ON STRESS AND ITS MANAGEMENT AMONG HOSPITAL EMPLOYEES}

\section{General instructions}

1. Dear respondent you are requested to carefully answer these questions

2. You are provided with questionnaire on stress assessment and management

3. The information provided by you will be kept confidential and used only for research purposes

4. You are requested to answer the question by making appropriate tick mark.

\section{Description of tool}

Tool is divided into two section and containing 22 questions.

\section{(A) Demographic variable}

Age:

Sex:

(B). Questionnaire

Q1. Are you content with the performance you gave at your institute? Yes/No

Q2. Do you fear about the quality of your performance? Yes/No

Q3. Do you work more than eight hour? Yes/No

Q4. Do you worry about colleague's opinion about you? Yes/No

Q5. Do you feel stress sometime? $\quad$ Yes/No

Q6. Is work load the reason of your stress? Yes/No

Q7. Do you discuss your problem with friend, spouse or any other person close to you?

Q8. Do you get tensed at non-achievement of your target?

Q9. Is there any effect of work on your health? $\quad$ Yes/No

Q10. Do you plan your work before doing? Yes/No

Q11. You have an important function at home and your supervisor asks for extension of $\begin{array}{ll}\text { duty, do you agree? } & \text { Yes/No }\end{array}$

Q12. Is there any conflict among staff? $\quad$ Yes/No

Q13. Is the conflict resolved in time? Yes/No

Q14. Do employees support each other? Yes/No

Q15. Are the strategies effective that are used by your institute to manage stress of employees? Yes/No

Q16. Is your social life balanced? $\quad$ Yes/No

Q17. Are your stressed because of your family problem? Yes/No

Q18. Do you try to find any solution for the problem of your stress? Yes/No

Q19. Do you try to find solution in practicing your religion? Yes/No

Q20. Do you regularly spend time on entertainment? Yes/No 
Easily Publish Textbooks, Course materials, and Research Thesis. Sell your work on REDSHINE or buy the books you need immediately.
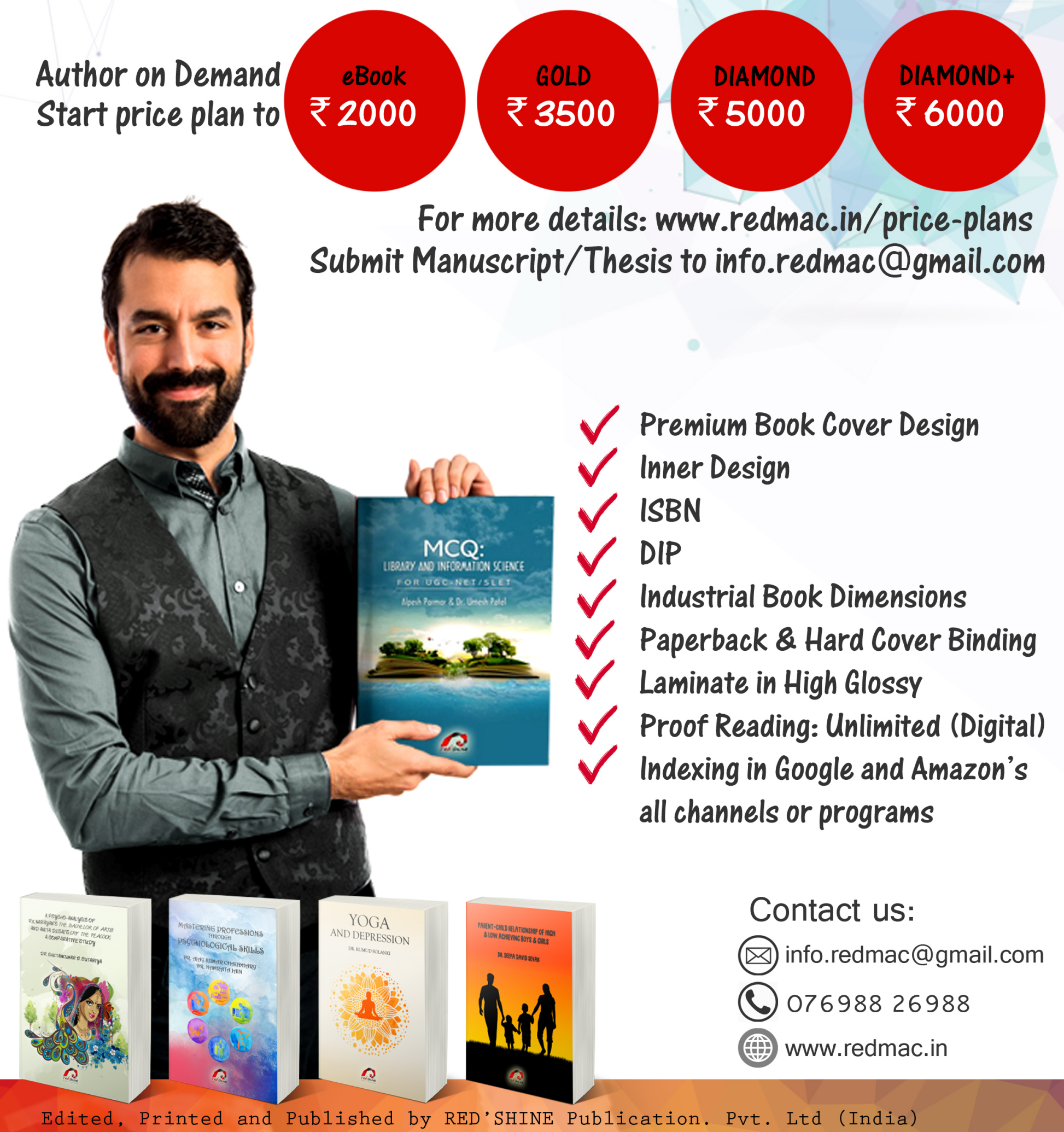

on behalf of the RED'MAC Networks. Inc. And Indian Psychological Association

86: Shradhdha, 88 Navamuvada, Lunawada, Gujarat-389230

www.redmac.in | info.redmac@gmail.com | Co.no: +917698826988

www.ijip.in | info.ijip@gmail.com | journal@ijip.in

Indexed at

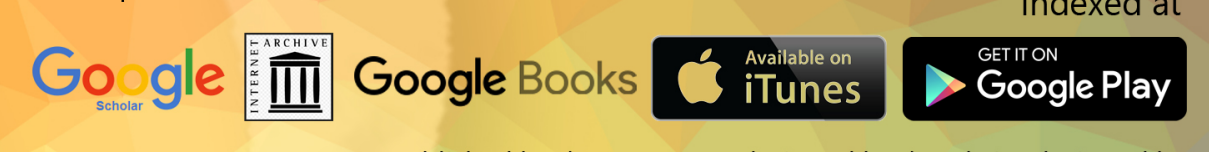

